Jurnal Pengajian Melayu - JOMAS, Jilid 31, 2020: 169-183

\title{
SKALA KECIL, IDEA BESAR: KRITIKAN NARATIF TERHADAP KARYA-KARYA TEATER ALTERNATIF DI STOR TEATER DBP
}

\author{
(SMALL SCALE, BIG IDEAS: NARRATIVE CRITICISM \\ OF ALTERNATIVE THEATRES IN STOR TEATER DBP)
}

\author{
Syahrul Fithri Musa \\ Fakulti Filem, Teater dan Animasi \\ Universiti Teknologi MARA \\ Kampus Puncak Perdana, Shah Alam \\ Malaysia \\ sfitri315@uitm.edu.my \\ Mohd Effindi Samsuddin \\ Akademi Pengajian Melayu \\ Universiti Malaya, Kuala Lumpur \\ Malaysia \\ effindi@um.edu.my
}

Received: 12 December 2019; Accepted: 17 Februari 2020

\begin{abstract}
This paper aimed to discuss chosen alternative theatre writings which had been staged at Stor Teater Dewan Bahasa dan Pustaka (DBP) from 2003 to 2013. The chosen shows were picked from a pool of various works done by playwright-directors of different age groups, educational backgrounds and experiences in theatre such as Dinsman, Nam Ron, A. Wahab Hamzah, Fasyali Fadzly and Aloy Paradoks. A narrative criticism analysis was then made upon five informants who were also playwrights and directors of ten shows presented at the Stor Teater DBP, Kuala Lumpur, throughout 11 years from 2003 to 2014. The analysis was made to understand their preferences and approaches to writing. This paper highlighted aspects of their writings, for example, idea, process and space, to retrieve early evidence of the concept 'small scale, big ideas' within alternative Malay theatre. Results showed two approaches that have been utilised - writing based on a prior full narrative or a performance concept - thereby showing an understanding of distinct creative processes. This phenomenon is related to the ideologies held by each of the playwright-director studied.
\end{abstract}

Keywords: Theatre, narrative criticism, scriptwriting Malay alternative theatre, performing arts. 


\begin{abstract}
Abstrak
Kertas kerja ini bertujuan membincangkan mengenai idea penulisan karya-karya teater alternatif terpilih yang dipentaskan di Stor Teater DBP pada tahun 2003 hingga 2013. Pementasan-pementasan teater terpilih diambil daripada karya penulis-pengarah yang mempunyai latar belakang daripada pelbagai segi faktor umur, pendidikan dan pengalaman mereka dalam dunia teater seperti Dinsman, Nam Ron, A Wahab Hamzah, Fasyali Fadzly, dan Aloy Paradoks. Analisis kritikan naratif dilakukan terhadap lima orang informan, iaitu penulis-pengarah bagi sepuluh pementasan yang pernah dipersembahkan di Stor Teater Dewan Bahasa dan Pustaka, Kuala Lumpur dari tahun 2003 hingga 2014 untuk melihat kecenderungan dan pendekatan penulisan setiap seorang dari mereka. Beberapa aspek yang diperbincangkan dalam kertas kerja ini seperti idea, proses penulisan, dan ruang, adalah untuk mencari pembuktian awal mengenai konsep skala kecil, idea besar yang diketengahkan terhadap teater alternatif Melayu. Hasil penyelidikan yang diperoleh menunjukkan terdapatnya dua pendekatan yang digunakan iaitu sama ada dengan menulis berdasarkan idea naratif penuh terlebih dahulu ataupun berdasarkan konsep persembahan terlebih dahulu, telah memberi gambaran kepada proses kreatif yang berbeza. Ini bersangkut paut dengan faktor-faktor yang melibatkan ideologi setiap orang penulis-pengarah tersebut.
\end{abstract}

Kata kunci: Teater, Kritikan naratif, Penulisan Skrip Teater Alternatif Melayu, Seni Persembahan.

\title{
Pengenalan
}

Kewujudan Stor Teater DBP sebagai sebuah ruang alternatif bagi pengkarya-pengkarya teater di Kuala Lumpur tidak hanya bergantung pada kreativiti teaterikal sebagai tarikan kepada khalayak penonton. Malah, kekuatan isi naratif turut menjadi modal penting bagi penulis-pengarah terlibat menghidangkan aspek pemikiran. Oleh itu, kekuatan naratif karya-karya teater alternatif Melayu di Stor Teater DBP dapat memberikan kepuasan terhadap pengikutnya dalam berwacana tentang isu-isu, permasalahan, persoalanpersoalan hidup yang diutarakan. Terdapat penulis-pengarah yang meletakkan idea penulisan mereka mengatasi hal-hal teaterikal yang sememangnya mempunyai limitasi terhad di ruang sekecil Stor Teater DBP. Justeru konsep "skala kecil, idea besar" dijadikan satu analogi dalam penulisan ini untuk memberi gambaran terhadap karya-karya yang mendokong idea besar ditransformasi ke atas pentas kecil di Stor Teater DBP dari tahun 2003 hingga 2014. Penumpuan khusus juga disasarkan kepada penulis-pengarah, iaitu penulis skrip yang juga bertindak sebagai pengarah terpilih yang mementaskan teater alternatif Melayu. Penulis-pengarah yang dipilih adalah seperti dalam Jadual 1.1.

Jadual 1.1: Senarai Penulis-Pengarah dan Karya Pementasan di Stor Teater DBP yang Dipilih

\begin{tabular}{|c|c|c|c|}
\hline No. & Penulis-Pengarah & Karya yang dipilih & $\begin{array}{c}\text { Tahun } \\
\text { dipentaskan }\end{array}$ \\
\hline \multirow[t]{2}{*}{1.} & Dinsman & Tamu Dari Medan Perang & 2006 \\
\hline & (Shamsudin Osman) & Menunggu Kata Dari Tuhan & 2009 \\
\hline \multirow[t]{2}{*}{2.} & Nam Ron & Matderihkolaperlih & 2004 \\
\hline & (Shahili Abdan) & Laut Lebih Indah dari Bulan & 2006 \\
\hline \multirow[t]{2}{*}{3.} & A. Wahab Hamzah & Hering & 2005 \\
\hline & & Peristiwa Malam Itu & 2008 \\
\hline \multirow[t]{2}{*}{4.} & Aloy Paradoks & Neo-Romantik & 2008 \\
\hline & (Nurul Asyikin Abdul Hamid) & Merocok-rocok & 2011 \\
\hline \multirow[t]{2}{*}{5.} & Fasyali Fadzly & Kotak Hitam & 2011 \\
\hline & & Teater Juta-juta & 2013 \\
\hline
\end{tabular}

e ISSN 2735 - 1904

https://doi.org/10.22452/JOMAS.vol31no1.11 
Skala Kecil, Idea Besar: Kritikan Naratif

Terhadap Karya-Karya Teater Alternatif Di Stor Teater DBP

Berdasarkan jadual tersebut, terdapat sepuluh pementasan teater oleh lima orang penulis-pengarah tersebut diberikan tumpuan dalam menganalisis aspek naratif sebagai asas kreativiti pementasan. Penulispengarah yang dipilih terdiri daripada latar belakang yang berbeza, iaitu mereka yang mempunyai pengalaman dan yang mempunyai latar akademik secara formal dalam bidang teater. Dinsman dan A Wahab Hamzah merupakan penulis-pengarah senior yang mempunyai pengalaman mementaskan teater sejak tahun 1970-an. Tiga penulis-pengarah yang lain pula tergolong daripada mereka yang lebih muda dan mempunyai latar belakang akademik secara formal dalam bidang teater dari institusi pengajian tinggi tempatan dan luar negara. Berdasarkan latar belakang yang berbeza, kajian ini dapat melihat kepelbagaian corak idea naratif dan pendekatan praktikal yang dilakukan oleh mereka.

Penulisan skrip teater yang dihasilkan di Stor Teater DBP pada awal tahun 2003 sehingga 2014 dilihat sebagai satu tempoh masa kebanyakan skrip yang ditulis adalah untuk dipentaskan semata-mata dan bukannya untuk diterbitkan sebagai bahan pembacaan. Berdasarkan sepuluh karya yang dipilih, hanya empat karya, iaitu Menunggu Kata dari Tuhan, Tamu dari Medan Perang, yang dicetak dan diterbitkan dalam bentuk buku secara berasingan. Teks Matderihkolaperlih dan Laut Lebih Indah dari Bulan diterbitkan dalam satu buku yang sama sebagai kompilasi bagi karya-karya Nam Ron. Teks-teks selain yang disebutkan tadi tidak diterbitkan dan tiada dalam simpanan penulis-pengarah itu sendiri. Bagi tujuan penyelidikan, penyalinan semula dalam bentuk teks berdasarkan rakaman video yang diperolehi telah dibuat sebagai bahan rujukan. Salinan bahan-bahan rakaman video tersebut telah ditranskrip berdasarkan sumber asal yang diperolehi dari Pusat Dokumentasi, Dewan Bahasa dan Pustaka Kuala Lumpur.

Tradisi penghasilan penulisan skrip untuk tujuan pementasan ini sedikit sebanyak telah mewujudkan satu gaya kerja kreatif yang ekonomikal berdasarkan keperluan skala sesebuah pementasan itu diusahakan, iaitu skrip yang dihasilkan itu ditulis sendiri oleh pengarah pementasan tersebut. Secara umum, gaya kerja kreatif ekonomikal ini dapat mengurangkan kos pembayaran atau honorarium, dan yang lebih utama adalah idea pengkaryaan itu sendiri dapat ditunjangi oleh hanya seorang individu sahaja. Dalam konteks proses pengkaryaannya juga berbeza apabila objektif dari awal proses menulis teks tersebut telah berkompromi dengan aspek-aspek pementasan di ruang seperti di Stor Teater DBP secara khususnya.

Dalam kalangan penulis-pengarah teater alternatif Melayu di Stor Teater DBP dilihat mempunyai pendekatan berbeza dalam menjalankan proses penulisan teks yang terpilih berdasarkan cara dan keselesaan masing-masing. Kajian ini memberi pendekatan terhadap teori kritikan sastera dengan penumpuan terhadap aspek naratif. Menurut Fauzi Hassan et al. (2019), "Kritikan merujuk kepada aspek penilaian, pentafsiran, penganalisisan, dan penghuraian" (p.5). Unsur-unsur kritikan naratif yang terdiri dari ruang (latar tempat dan masa), watak dan perwatakan, narator (unsur kejadian), hubungan dengan penonton, tema, dan persoalanpersoalan perlu diteliti. Situasi ini penting bagi melihat proses kerja penulisan itu disempurnakan dalam menyampaikan maksud kreatif dan ideologi mereka. Seterusnya, cara teks tersebut ditransformasikan ke pentas melalui unsur-unsur teaterikal juga perlu diambil perhatian. Proses kerja kreatif sebagai penulis dan sekaligus pengarah kepada karya itu sendiri memberikan pilihan idea dan kebebasan kepada kelimalima penulis-pengarah terpilih untuk memulakan proses pengkaryaan itu dengan naratif ataupun konsep pementasan terlebih dahulu.

\section{Hasil dan Pembahasan}

Terdapat tiga aspek utama yang diketengahkan yang menggariskan kepentingan asas karya yang diambil kira oleh penulis-pengarah ini dalam proses kerja kreatif apabila dibawa ke pentas. Tiga aspek utama yang dimaksudkan ialah tentang idea dan proses penulisan teks, ruang pementasan, dan latar masa dan tempat. Ketiga-tiga aspek ini turut dapat menjadi kayu ukur terhadap corak atau gaya sekaligus mengenai ideologi penulis-pengarah teater alternatif Melayu. Analisis terhadap idea penulisan sesebuah karya sastera seperti drama atau teks persembahan adalah satu kaedah yang mampu mencungkil ideologi pengarangnya. Sebelum

e ISSN 2735 - 1904

https://doi.org/10.22452/JOMAS.vol31no1.11 
penemuan bagi narratology postclassical (naratologi pasca-klasikal), Culler (1994, p. 141) menjelaskan bahawa ideologi dalam fiksyen atau karya sastera adalah yang paling sering dikaji sebagai "pelbagai stereotaip budaya atau ilmu pengetahuan yang diterima yang terkandung dalam naratif dan diterima oleh pembaca sebagai semulajadi dan jelas".

Ideologi membentuk sebahagian daripada 'kod budaya' yang merujuk kepada badan pengetahuan budaya diaktifkan oleh naratif dan 'menghasut' pembaca untuk menerima storyworld (dunia fiksyen) sebagai munasabah dan boleh dipercayai. Pada permulaannya, tradisi ini, yang dimulakan oleh Hamon Greimas, terus berpegang kepada teks itu sendiri sebagai sumber 'kesan ideologi'. Kesan itu dianggap sebagai 'tertulis dalam teks,' iaitu sebagai normatif dan kontradiksi sistem nilai. Korthals Altes memberi tumpuan kepada teks yang mempengaruhi pembaca berdasarkan analisis awalnya mengenai kesan nilai dalam naratif. Kesan nilai tersebut dapat dianalisis berdasarkan struktur teks (contohnya organisasi plot, watak, perwatakan dan dialog), dan seterusnya 'kesan ideologi' berada di ruang bawah sedar (Culler, 1994, p.141).

Teater sebagai salah satu cabang seni budaya mampu secara holistik memperlihatkan ideologi penulis-pengarah sekaligus mewujudkan kelompok yang menggerakkan aliran teater pada sesuatu zaman atau era. Ideologi penulis-pengarah dalam satu gerakan atau kelompok yang terbina dari satu justifikasi prinsip yang berasas seperti teater alternatif Melayu adalah representasi secara menyeluruh mengenai bentuk teater alternatif di Malaysia. Selain dari "bentuk teater tradisional yang ditangani kelangsungannya oleh kementerian dan agensi kerajaan serta agensi swasta yang lain" (Rahmah Bujang, 2007, p. 154), teater alternatif Melayu juga turut memainkan peranan yang sama dalam memelihara kepentingan nasional dari segi pengisian nilai naratif dan estetika di dalamnya.

\section{Idea dan Proses Penulisan Teks}

Kesemua sepuluh skrip teater alternatif Melayu di Stor Teater DBP yang dipilih telah dihasilkan oleh pengarahnya sendiri, sama ada ditulis berdasarkan konsep pementasan yang telah difikirkan atau dirancang terlebih dahulu ataupun bertolak daripada idea naratif naskah itu sendiri. Dinsman, Nam Ron dan A. Wahab Hamzah misalnya, lebih cenderung bermula dengan idea cerita terlebih dahulu sebelum memikirkan tentang idea cara mentransformasikan idea teks dalam bentuk pementasan.

Dinsman, dalam proses menghasilkan teks Tamu dari Medan Perang, telah menyesuaikan sebuah karya yang bertajuk Siapakah Takutkan Amerika?, iaitu sebuah lagi karya beliau yang masih belum dipentaskan, kepada sebuah teater berskala kecil yang bersesuaian dengan kapasiti ruang Stor Teater DBP. Bagi tujuan pementasan di Stor Teater DBP, Dinsman telah meminimumkan elemen-elemen teaterikal terutamanya dari segi jumlah pelakon yang terlibat dan aspek teaterikal lain. Pada asalnya untuk teks Siapakah Takutkan Amerika telah dicadangkan dibuat mengikut fasiliti yang tersedia ada di Panggung Sari, Istana Budaya yang berkapasiti 1400 penonton. Walau bagaimanapun perancangan Dinsman untuk mementaskannya di Istana Budaya pada ketika itu tidak kesampaian. Oleh kerana itu, Dinsman telah menulis skrip Tamu dari Medan Perang iaitu satu versi skala yang lebih kecil tetapi menggunakan idea cerita yang sama seperti skrip Siapakah Takutkan Amerika untuk dipentaskan di Stor Teater DBP.

Bagi teater Menunggu Kata Dari Tuhan pula, Dinsman mendapat ilham berdasarkan sebuah hadis yang panjang. Dalam banyak pembacaannya ketika mempelajari ilmu hadis, beliau tertarik dengan sebuah hadis sahih yang diriwayatkan oleh Bukhari dan Muslim, diceritakan sendiri oleh Kaab bin Malik kepada anak beliau, Abdullah Bin Kaab (Dinsman, 2009, p.82). Dinsman menganggap hadis tesebut mempunyai keistimewaannya berbanding hadis-hadis lain yang pernah dibacanya. Malah, hadis tersebut dikatakan mempunyai naratifnya yang sedia ada serta sesuai untuk diadaptasikan kisahnya menjadi sebuah teater. Menurut Dinsman (2009, p.82), "Perwatakan Ka'ab sewaktu dia menceritakan dilemanya itu adalah sebuah perwatakan yang sungguh dramatik dan teaterikal. Maka apa lagi! Untuk orang teater seperti

e ISSN2735 - 1904

https://doi.org/10.22452/JOMAS.vol31no1.11 
Skala Kecil, Idea Besar: Kritikan Naratif

Terhadap Karya-Karya Teater Alternatif Di Stor Teater DBP

saya, ini adalah sebuah bahan yang sangat baik untuk diolah menjadi sebuah karya teater". Bertolak dari itu, terhasillah Menunggu Kata Dari Tuhan yang memperkenalkan watak Kaab bin Malik, iaitu seorang sahabat Rasullullah SAW yang berhadapan dengan dilema, sama ada mahu berterus terang mengenai perkara sebenar atas kelalaian beliau tidak menyertai perang Tabuk atau berbohong dengan alasan-alasan yang dicipta. Dilema yang dihadapi oleh Kaab seperti ini turut menjadi kegemaran kepada Dinsman untuk dijadikan sebagai konflik utama dalam karya-karyanya sebelum ini seperti Protes (1972) dan Bukan Bunuh diri (1974). Kedua-dua karya Dinsman ini terkandung dalam kompilasi skrip teater Dinsman yang berjudul Bukan Bunuh Diri (1979) terbitan Dewan Bahasa dan Pustaka.

Teks teater Hering tulisan A Wahab Hamzah pula adalah hasil adaptasi dari salah sebuah cerpen daripada sepuluh cerpen yang terkandung dalam sebuah novel berjudul NaratifOgonshoto karya Sasterawan Negara ke-sepuluh, Anwar Ridhwan. Cerpen yang juga berjudul Hering tersebut telah dimuatkan dalam Dewan Sastera edisi bulan Ogos tahun 2000. A Wahab Hamzah tertarik dengan imej wanita yang diangkat dalam cerpen tersebut dan kemudiannya mengolah mengikut versinya sendiri di pentas teater. Hering versi teater ini menampilkan seorang watak perempuan iaitu anak kepada Timbalan Menteri yang menjadi tunjang cerita dan dua watak pembantu lelaki.

Menurut A Wahab Hamzah (temubual peribadi, 2016), setiap kali beliau mahu menghasilkan sebuah teater, jalan cerita akan diberikan penekanan terlebih dahulu. Keadaan ini berlaku pada kedua-dua teks Hering dan Peristiwa Malam Itu. Setelah skrip lengkap ditulis dengan beberapa ciri-ciri kelainan, barulah beliau bekerja dengan para pelakon. Dalam masa yang sama, sebagai seorang pengarah, beliau akan memikirkan konsep yang bersesuaian dengan kehendak cerita. Proses membuat teks Peristiwa Malam Itu pula datangnya dari pengalaman dan persoalan yang bermain dalam fikiran beliau sendiri ketika melihat situasi yang berlaku pada era Reformasi yang berlaku pada tahun 1998 di ibu kota Kuala Lumpur. Ketika itu, beliau yang secara langsung terlibat dalam gerakan Reformasi berpeluang menyaksikan kejadian penangkapan ramai reformis yang membuat demonstrasi jalanan. A. Wahab Hamzah pada peringkat awal proses menghasilkan teks tersebut memikirkan persoalan kegagalan seorang anggota polis menangkap seseorang yang dianggap penjenayah walaupun telah terlalu hampir untuk menangkapnya. Bertolak dari persoalan itu, maka lahirlah idea Peristiwa Malam Itu yang melibatkan adegan di antara watak seorang anggota polis dan seorang pemilik warung pada satu malam di tengah-tengah kotaraya Kuala Lumpur. Konsep cerita yang muncul terlebih dahulu telah dengan sendiri membentuk konsep persembahan Peristiwa Malam Itu. Selain itu karya Peristiwa Malam itu turut dijadikan sebagai saluran politik dan ideologi sepertimana yang diperkatakan oleh Effindi Samsudin (2007, p. 4) juga terjadi kepada Bangsawan "dalam melontar suara-suara propaganda positif, atau sebaliknya. Itupun setelah golongan-golongan tertentu menyedari kesenian ini amat berpotensi untuk menghimpun khalayak yang ramai tanpa paksaan".

Dua teks yang ditulis Nam Ron pula, iaitu Matderihkolaperlih dan Laut Lebih Indah dari Bulan turut sama dicetuskan dari idea penulisan terlebih dahulu. Nam Ron memberitahu pengkaji pengalaman mula-mula menulis teks Matderihkolaperlih adalah sewaktu beliau mengikuti bengkel di Bali bersama peserta-peserta lain yang pernah mengikuti Asian Theatre Practise 1 di Jepun. Dalam satu sesi, pesertapeserta bengkel termasuk Nam Ron diberikan kertas kosong dan pen untuk menulis apa sahaja tanpa henti sejurus menjalankan aktiviti rehat minda bawah sedar (subconscious). Hasil dari latihan tersebut, Nam Ron berjaya menghasilkan satu draf kasar dan kemudiannya diperkemaskan strukturnya dan memasukkan unsur-unsur dramatik (Temubual peribadi, 2016).

Naratif Matderihkolaperlih diilhamkan dari kisah hidupnya sendiri yang melihat pelbagai kejadian yang berlaku disekelilingnya ketika membesar di Kuala Perlis. Menurut Nam Ron (2012, p. 13), "Matderihkolahperlih sebenarnya kekacauan aku masa kecil di Perlis. Membesar tanpa mengenali bapak sehingga usia tujuh belas tahun bukan mudah seperti disangka, ditambah dengan kemiskinan menjadikan jiwa jadi kacau". Watak Mat Derih itu sendiri diinspirasikan dari perwatakan abang kandungnya sendiri. Kemiskinan menjadikan seseorang seperti abangnya menjadi kacau pada waktu muda. Ilham daripada

e ISSN2735 - 1904

https://doi.org/10.22452/JOMAS.vol31no1.11 
beberapa kejadian sebenar itu diadun dengan imaginasi untuk kesan dramatik yang lebih baik serta persoalan-persoalan yang disesuaikan dengan isu-isu semasa. Latar masa bagi teks ini diambil berdasarkan keadaan semasa yang menyaksikan survival politikus-politikus di Malaysia beretorik tentang kehidupan persis gelagat watak Mat Derih yang beraksi sebagai penjual ubat kaki lima di tengah-tengah kotaraya Kuala Lumpur (Nam Ron, 2012, p. 13).

Seperti Matderihkolaperlih, teks Laut Lebih Indah dari Bulan juga turut melalui proses penulisan yang sama dan turut diinspirasikan berdasarkan kejadian sebenar. Kes rogol dan pembunuhan kejam yang berlaku pada tanggal 25 Disember tahun 2003 terhadap Noritta Samsuddin telah dijadikan konsep penceritaan asas kepada teks tersebut. Nam Ron telah melihat dari perspektif isteri kepada seorang pembunuh dan perogol (tanpa merujuk secara terang terhadap kes sebenar) yang menceritakan semula setiap kenangan dari detik pertemuan, percintaan, perkahwinan, hubungan suami isteri sehingga membawa kepada perubahan sikap suami dan terjadinya tragedi pembunuhan. Permainan emosi dan konflik dalaman watak Indah dalam Laut Lebih Indah dari Bulan menjadi fokus utama Nam Ron dalam membina detik-detik aksi dramatik persembahan biarpun cuma bergantung kepada teks berbentuk monolog. Laut Lebih Indah dari Bulan yang berdurasi 60 minit, pernah dipentaskan di Taman Budaya Kuala Lumpur buat pertama kali dan dilakonkan oleh Junainah M. Lojong sebagai projek akhir Sarjana Muda Seni Persembahan di Universiti Malaya. Karya ini menurut Nam Ron (2012, p. 70) adalah kesinambungan daripada karya beliau yang berjudul Aku Nak Jadi Bintang yang turut menggunakan tema sama, iaitu cinta, rumah tangga dan seks seorang manusia tetapi dari sudut pandangan seorang kekasih.

Bagi penulis-pengarah baharu dan yang lebih muda seperti Fasyali Fadzly dan Aloy Paradoks berdasarkan keempat-empat karya teater mereka yang dipilih, kedua-duanya lebih selesa meletakkan konsep persembahan terlebih dahulu sebelum membentuk naratif. Fasyali Fadzly pada peringkat awal mendapatkan idea mementaskan Kotak Hitam, mempunyai persoalan yang bermain dalam fikirannya untuk menggabungkan lakonan pentas dan lakonan skrin dalam satu masa. Beliau terlebih dahulu membuat eksplorasi teknik dua genre seni tersebut dan akhirnya terciptanya idea seorang pelakon memainkan dua karektor berbeza dalam dua medium berbeza yang dipersembahkan secara langsung. Begitu juga dalam proses penciptaan karya Teater Juta-juta, Fasyali Fadzly memberitahu bahawa beliau memikirkan konsepnya terlebih dahulu berdasarkan pengalaman mengadakan latihan praktikal di Istana Budaya dimana satu ketika beliau berada dalam satu sesi perbentangan projek dan melihat model set yang digerak-gerakkan oleh seorang sinografer. Menurut Fasyali Fadzly (Temu bual peribadi, 14 April 2016), "Saya tengok keseluruhan presentation tu boleh jadi satu teater dan saya fikir nak buat macam tu." Setelah skrip ditulis, apa yang diimaginasikan tidak tercapai sepenuhnya kerana perlu diubah mengikut kapasiti tema cerita itu sendiri.

Aloy Paradoks juga secara jelas mengakui bahawa beliau adalah seorang yang terbiasa dengan cara memikirkan idea konsep persembahan terlebih dahulu sebelum datangnya naratif (temu bual peribadi, 23 Mei 2016). Dalam Merocok-rocok, beliau memikirkan konsep untuk menggabungkan elemen teater tradisional, sama ada Mek Mulung, Mak Yung, Menora, ataupun Randai dengan cerita isu-isu kontemporari setelah mendapat pendedahan secara formal ketika menuntut teater di Akademi Seni Budaya dan Warisan (ASWARA). Menurut Aloy Paradoks (Temubual peribadi, 23 Mei 2016), "Kita nak gabungkan yang tradisional tu supaya orang muda tahu. Memang saya fikirkan konsep dulu. Okey, aku nak buat randai, konsep full randai, ada muzik walaupun tak dapat yang tradisionallah, maksudnya form randai tu ada tapi cerita, cerita moden. Itu idea Merocok-rocok tu sebenarnya. Idea cerita tu datang selepas konsep. Saya orangnya begitu. Macam tu juga dengan Neo Romantik." Pendekatan hybrid yang ditunjukkan oleh Aloy Paradoks ini memberikan satu contoh gabungan unsur-unsur tradisi dan moden digunakan untuk mencorak bentuk pementasan sebagai docurum, iaitu cuba mengadaptasi karya mereka dengan citarasa penonton dan konsep realiti masa kini.

e ISSN 2735 - 1904

https://doi.org/10.22452/JOMAS.vol31no1.11 
Skala Kecil, Idea Besar: Kritikan Naratif

Terhadap Karya-Karya Teater Alternatif Di Stor Teater DBP

Dalam Neo Romantik, Aloy Paradoks bermain dengan masa. Beliau menggunakan kebolehan pelakon untuk menggunakan teknik imbas muka (flash forward), dan imbas kembali (flash back). Di samping itu, beliau juga menggunakan kebolehan pelakon membuat improvisasi cerita mengikut acuan yang ditetapkan oleh penonton dalam salah satu babak pementasan. Secara asasnya, Aloy Paradoks membayangkan Neo Romantik ketika pementasannya, penonton akan turut serta berperanan memberikan hala tuju kepada pengisian teater tersebut. Beliau mengatakan bahawa hal ini dipengaruhi dengan minatnya terhadap konsep forum theatre yang diketengahkan oleh aktivis teater Brazil, Augusto Boal (Aloy Paradoks, temu bual peribadi, 23 Mei 2016).

\section{Ruang (Tempat Pementasan), Latar Masa dan Latar Tempat}

Ketika memasuki mana-mana ruang pementasan teater, para penonton dalam keadaan dibawah sedar sebenarnya memasuki satu ruang artistik yang spesifik. Suasana (ambience) artistik yang diciptakan dalam ruang itu sekali gus membangkitkan reaksi dan tindak balas dari penonton yang hadir. Menurut Jones (2002, p. 3), reaksi penonton ketika melangkah kali pertama ke dalam panggung teater menjadi salah satu bahagian dari keseluruhan pengalaman teaterikal. Tambah Jones (2002, p. 2) lagi, "Terdapat beberapa dimensi yang mempengaruhi perjalanan masuk penonton ke dalam panggung dan beberapa persoalan perlu terjawab. Pertama, bagaimana keadaan ruang pementasan teater yang dimasuki penonton? Seterusnya, dari mana penonton datang sebelum memasuki ruang pementasan yang spesifik? Dalam erti kata lain, apakah ruang lain yang terdapat sebelum pintu masuk ruang pementasan tersebut?". Apabila para penonton mula memasuki ruang teater, beberapa perkara utama yang harus diberikan perhatian adalah cara ruang tersebut dibahagikan. Kedudukan tempat duduk penonton juga memainkan peranan terhadap hubungannya dengan pementasan, sama ada ia terpisah ataupun berada dalam satu ruang yang sama. Menurut Natalie (2009), ciri-ciri utama sebuah black box itu secara asasnya adalah kecil, berbentuk segiempat tepat, hitam dan mempunyai tempat duduk penonton yang fleksibel. Dengan kemunculan terlalu banyak teater black box di Amerika Syarikat pada era 1960-an dan 1970-an, ruang yang menghubungkan antara pelakon dan penonton sentiasa berubah-ubah dan sentiasa memberikan cabaran kepada para pereka dan pengarah.

Ruang pementasan bagi semua sepuluh teks adalah ruang fleksibel (flexible theatre), eksperimental atau juga dikenali sebagai black box theatre (teater kotak hitam), Stor Teater DBP. Ruang yang berkapasiti penonton tidak melebihi seratus lapan puluh orang dalam satu masa (termasuk yang duduk di atas lantai) ini mempunyai ciri-cirinya yang tersendiri terutama dari segi kedudukan pelakon dan penonton yang tidak ditetapkan dan juga berubah mengikut keperluan pementasan atau kehendak pengarah. Namun, terdapat juga platform yang disusun bertingkat seperti tangga di bahagian belakang kiri dan kanan sebagai tempat duduk penonton yang tetap. Bahagian dinding lantai dalam Stor Teater DBP juga dicat dengan warna hitam bertepatan dengan spesifikasi sebuah black box. Warna hitam pada keseluruhan black box bukan sahaja menimbulkan perasaan berada di mana-mana (sense of anyplace), malah turut memberikan kesan yang lebih berintensiti dan jelas kepada warna, rekaan, dan posisi pencahayaan pada lantai ruang pementasan.

Ruang menjadi aspek penting bagi penulis-pengarah dalam menetapkan had serta memberikan pertimbangan terhadap rupa, saiz, dan juga konsep berkenaan hubungan pelakon dan penonton. Perkara ini menjadi sesuatu yang boleh difikirkan sejak dari proses penulisan dan juga dimasukkan ke dalam skrip sebagai rujukan ketika mengarah dan membuat rekaan. Merujuk kepada apa yang diperkatakan oleh Jones (2002, p. 4), iaitu "Ruang teater adalah unsur yang sangat penting untuk proses rekaan. Ia boleh menjadi sesuatu yang mampu mewujudkan suasana teaterikal, namun harus juga memikirkan soal keselesaan dan juga harus berfungsi dengan baik". Ruang dan tempat pementasan juga turut menjadi unsur yang mempunyai kaitan pengaruh yang dekat dengan latar masa dan tempat cerita. Menurut Liina (2002, p. 364), "Setiap ruang mengandungi dunia yang lain. Aktiviti ritual dan estetika mentransformasi ruang itu kepada heterotopia. Teater dalam pelbagai ruang berhubung kait dengan prinsip tersebut".

e ISSN 2735 - 1904

https://doi.org/10.22452/JOMAS.vol31no1.11 


\section{Latar Masa dan Latar Tempat}

Sejak permulaan sejarah teater itu sendiri, pementasan teater telah membawa para penontonnya menjelajah ke beberapa latar masa dan tempat yang berlainan secara imaginatif dengan hanya menuntut para penontonnya duduk di tempat duduk dalam sebuah panggung. Sebagai contoh, dalam babak 3 dan 4 teks klasik Antony and Cleopatra, Shakespeare telah membawa penonton menjelajah dua puluh lapan lokasi berlainan dalam masa tiga hari (Grams, 2017, p. 2). Keadaan ini merupakan satu pengalaman imaginatif yang sekaligus menghubungkan pemain, penonton, ruang, latar tempat dan latar masa. Teater, sebagai sebuah cabang seni persembahan yang terhubungkait dengan aksi dan imaginasi menyediakan satu 'jendela' kepada dunia lain yang memberikan kebebasan kepada penulis-pengarah memilih sebarang kejadian yang berlatar masa dan latar tempat bersesuaian dengan keperluan yang dimiliki. Menurut Grams (2017), "Dalam teater, kita tahu yang kita tidak dibawa menjelajah secara fizikal dalam masa dan tempat tersebut, tetapi memori kita merekodkan pengalaman yang kita pernah berada di situ". Menurut Liina (2002) pula, ruang imaginatif tercipta daripada persediaan tubuh dan psikologi pelakon atau karektor yang telah terlebih dahulu memahami dengan secukupnya sesebuah ruang dramatik dan seterusnya aspek sinografi memainkan peranan untuk mencipta "a lived space" (ruang sebenar) dari ruang yang tidak wujud.

Merujuk kepada sepuluh teater alternatif di Stor Teater DBP, dengan skala ruang yang terhad, latar masa dan tempat didapati bukanlah menjadi satu isu yang rumit untuk ditangani. Rata-rata penulis-pengarah terlibat masih bebas dan tidak terikat untuk menetapkan latar masa dan tempat dalam karya masing-masing. Sebahagiannya menggunakan konsep teater sebabak, iaitu satu konsep yang hanya melibatkan satu latar tempat dan satu latar masa sepanjang pementasan berlangsung. Pendekatan ini jelas dapat dilihat dalam teks-teks seperti Hering, Peristiwa di Malam Itu, Laut Lebih Indah dari Bulan, dan Kotak Hitam.

Hering, karya dan arahan A Wahab Hamzah telah mengambil latar tempat di sebuah rumah yang terletak di pinggir hutan. Walau bagaimanapun keterperincian mengenai lokasi sebenar berlakunya adeganadegan di dalam Hering tidak dinyatakan secara jelas dan berbeza dengan apa yang digambarkan oleh Anwar Ridhwan dalam novel Naratif Ogonshoto (novel asal sumber inspirasi). Anwar Ridhwan telah menetapkan latar lokasi yang terletak sebuah wilayah di negara Jepun. Pemilihan latar rumah dan geografi dalam Hering memberikan petunjuk kepada ciri-ciri yang ada pada karektor-karektor serta menyokong kepada premis cerita. Kawasan terpinggir (pinggir hutan) memberikan kesan keterasingan karektor-karektor dengan dunia luar sehinggakan tragedi pembunuhan yang berlaku kepada watak Pemburu ketika memburu di hutan menjadi lebih realistik dan menjadi misteri. A Wahab Hamzah jelas membiarkan latar tempat dan masa dalam Hering menjadi lebih fleksibel dan boleh 'berada dimana-mana' agar bersifat universal dan boleh diterima oleh penonton di Malaysia khususnya.

Begitu juga dengan Peristiwa di Malam Itu dilihat lebih jelas menyatakan mengenai latar tempat dan masa, sama ada dari segi pengisian penataan set dan juga dialog-dialog yang digunakan. Teater sebabak ini berlaku di sebuah warung makan milik seorang peniaga Melayu di pinggir bandaraya Kuala Lumpur. Keseluruhan kejadian dalam karya ini berlatar masa pada satu malam dalam tahun 2000. Latar tempat dan masa dalam Peristiwa di Malam Itu berhubung kait dengan peristiwa-peristiwa penting mengenai sosiopolitik yang berlaku pada ketika itu di Kuala Lumpur. Menurut A Wahab Hamzah, Peristiwa di Malam Itu mempunyai kaitan dengan situasi yang berlaku di Kuala Lumpur pada zaman Reformasi, iaitu kepercayaan masyarakat terhadap pihak berkuasa sedikit terhakis dan memberi kesan kepada usaha membanteras jenayah (A Wahab Hamzah, temubual peribadi, 7 April 2016).

Laut Lebih Indah dari Bulan turut mengambil latar masa kini iaitu awal era millenium dimana idea asalnya diilhamkan dari kejadian sebenar mengenai kes sensasi yang berlaku di Malaysia mengenai seorang wanita yang dirogol dan dibunuh pada tahun 2003 di Kuala Lumpur. Beberapa pernyataan mengenai latar secara terperinci turut dinyatakan di dalam teks melalui monolog watak Bulan yang memberi gambaran terhadap latar tempat. Dalam adegan 3 sebagai contoh, watak Bulan menyatakan keadaan tempat tinggal

e ISSN 2735 - 1904

https://doi.org/10.22452/JOMAS.vol31no1.11 
Skala Kecil, Idea Besar: Kritikan Naratif

Terhadap Karya-Karya Teater Alternatif Di Stor Teater DBP

beliau ketika bujang secara terperinci seperti berikut;

Aku ingat lagi rumah tu, dua tingkat. Tingkat bawah batu, tingkat atas papan. Tingkat atas ada empat bilik semuanya. Aku duduk kat bilik nombor 4, tingkat atas, nombor rumah 34, Lorong 2/1, Jalan Haji Rahman, Keramat, KL.

(Nam Ron, 2012, p.74)

Seterusnya dalam adegan 4, dalam monolog Bulan turut ada menyatakan lokasi tempat tinggalnya dan Laut selepas bergelar suami isteri. Selain memberikan latar belakang dan ciri-ciri geografi, Nam Ron secara jelas menyatakan tentang perubahan aspek sosio-ekonomi watak. Watak Bulan dalam adegan 4 memberitahu penonton pada awal perkahwinan, mereka menyewa sebuah apartment di Pandan Indan dengan keadaan keperluan yang paling asas. Kemudian selepas dua tahun berkahwin, Laut dapat pekerjaan baharu sebagai jurutera cari-gali minyak Petronas dan mereka berpindah dari Pandan Indah ke Damansara. Perkembangan dan perubahan sosio-ekonomi diperlihatkan dalam adegan ini yang turut menjadi faktor perubahan sikap yang berlaku pada watak Laut yang dijelaskan lagi dalam monolog Bulan yang seterusnya, iaitu:

\section{BULAN:}

Kami dah pindah dari Pandan Indah ke Damansara. Masa ni laut selalu out station, kadang-kadang berminggu-minggu ada masa berbulan-bulan. Aku pulak dah berhenti bekerja, dia nak aku duduk rumah je

(Nam Ron, 2012, p. 76)

Dalam adegan 3 turut dinyatakan tempat lain secara literal seperti di Hotel Concorde Bukit Bintang, dan Hard Rock Café di Kuala Lumpur yang sekaligus memberikan ciri-ciri khusus tentang aspek latar belakang sosial watak dalam karya tersebut yang telah berasimilasi dengan cara hidup masyarakat bandar dan moden. Tempat-tempat hiburan seperti Hard Rock Café yang dinyatakan dalam adegan 3 menjadi tempat pilihan bagi pasangan watak Bulan dan Laut makan malam dan seterusnya membuat lamaran perkahwinan.

Matderihkolaperlih pula membawa para penonton mengembara ke latar masa dan tempat yang berbeza-beza dari awal hingga akhir pementasan. Dari sudut pementasan, ruang yang dijadikan tempat beraksi pelakon adalah sebuah lantai yang kosong tanpa sebarang set dan props. Pelakon secara bermonolog mengisi ruang dengan aksi-aksi realistik dan turut memulakan pementasannya dengan menyapa para penonton secara terus dengan melontarkan persoalan realiti dan kontemporari mengenai perkaitan perbuatan menghisap rokok yang secara tidak langsung membantu membangunkan negara dari aspek pembayaran cukai yang tinggi. Perlakuan tersebut seakan membuka satu keadaan yang lebih bersifat 'perkongsian' pendapat antara pelakon (watak) dengan penonton sekaligus mencipta satu ruang yang sama seperti baris dialog di bawah:

(kepada penonton) Nak? Nak, ambil la. Pasal apa takut nak hisap rokok. Siapa yang tak bagi? Habaq mai dekat aku. Sapa kata salah? Hisap rokok ni sebenaqnya kita dok bantu negara jadi maju. Tiap tahun cukai rokok duk naik, pasai apa? Pasai nak buat gedung, nak buat sekolah, nak buat jalan, nak bayaq gaji menteri, bayaq gaji pegawai, gaji polis, gaji askar. Sari aku hisap dua kotaq besar, setahun 360 kali dengan dua sama dengan 720 kotak bersamaan dengan empat belas ribu empat ratus batang setahun. Jadi berapa banyak cukai aku bayaq dalam setahun?

(Nam Ron, 2012, p. 18)

e ISSN 2735 - 1904

https://doi.org/10.22452/JOMAS.vol31no1.11 
Sebuah lagi karya yang mengetengahkan latar tempat dan masa kini adalah Kotak Hitam. Karya dan arahan Fasyali Fadzly ini walaupun tidak dinyatakan secara terperinci mengenai latar tempat dan masanya, namun watak dan isu semasa yang diangkat bersama setting moden, iaitu ruang tamu di sebuah pangsapuri memberi gambaran jelas latar belakang zaman sekarang (pada masa ia dipentaskan pada tahun 2011). Dalam Kotak Hitam, watak Mamat diperlihatkan sebagai seorang anak muda bujang yang tinggal berseorangan di sebuah pangsapuri, obses dengan televisyen yang banyak menyiarkan rancangan realiti seperti yang dinyatakan sejak awal dialognya di bahagian pertama teks.

MAMAT:

(di telefon)

(...) Hah? Ha'ah, saya sorang. Mana ada sesiapa kat sini. Diorang semua tak suka duduk kat sini. Ha'ah. Saya lagi suka tinggal sorang-sorang. Tengok TV. Tak taulah. Awak tengok tak konsert semalam? Idola Masyarakat. Oh, tak apa. Ada ulangan, kan? Nanti awak tengoklah. Mamat yang menyanyi lagu Inggeris tu dah nak terkeluar. Ha'ah. Sebab dia bergaduh dengan seorang lagi peserta. Taklah, mana ada diorang berlakon. Semua tu real tau tak. Dia betul-betul marah kali ni. Taklah sayang. Dah tentu TV tunjuk semua tu, mestilah betul-betul. Tak mungkin diorang tu semua berlakon. Memanglah rancangan tu realiti TV tapi yang tu real tau.

(Fasyali Fadzly, 2012)

Fenomena realiti TV melanda seluruh dunia sejak awal tahun 1990 dan semakin popular pada awal 2000 dengan kejayaan siri popular Survivor, Idol dan Big Brother (Hill, Annet, 2005) telah menjadi indikasi kepada latar zaman dalam Kotak Hitam. Set ruang tamu moden dengan perabot moden dan ringkas serta sebuah peti televisyen berskrin leper turut memenuhi ciri-ciri sezaman dan mencipta karektor sosial secara tidak langsung. Walaupun watak Mamat dalam Kotak Hitam dilihat bebas tetapi keadaan jiwa dan mindanya obses serta terikat dengan objek bernama televisyen menjadikan ia dilihat berada dalam satu ruang seperti yang diperkatakan oleh Michel Foucault sebagai konsep 'heterotopias penyimpangan' (heterotopias of deviation). Melalui konsep itu ruang yang didiami oleh individu yang tingkah laku menyimpang daripada norma masyarakat (Knight, 2014, p. 18). Fasyali Fadzly sebagai penulis dan pengarah seakan mahu mewujudkan satu ruang yang menggambarkan social disorder yang berlaku dalam masyarakat pada ketika itu. Melalui watak Mamat dengan tingkah laku obsesnya sehingga berilusi bercakap dengan dirinya sendiri di hadapan kaca televisyen. Secara tidak sedar telah menjadikan Kotak Hitam sebagai satu pementasan yang boleh dilihat sebagai cerminan kepada latar masa dan tempat kontemporari.

Sejak kemunculan persembahan-persembahan teater pasca-modenisme, ia telah menghasilkan pandangan yang berbeza terhadap ruang, iaitu ruang sebagai metafora, dan ruang sebagai paradigma khayalan. Munculnya pelbagai gaya terkini dalam dunia teater, jelas bahawa salah satu hubungan utama antara kedua-dua aspek itu adalah untuk mengintegrasikan ruang sebenar dan khayalan. Hubungan antara ruang realiti dan khayalan ini dapat dilihat dalam teks Teater Juta-juta yang pada keseluruhannya telah menetapkan latar zaman kini dengan penampilan isu, watak-watak, serta aspek teaterikal yang relevan dengan keadaan semasa. Kombinasi setiap aspek tersebut mengisi ciri-ciri ruang semasa sekaligus menyokong isu dan persoalan yang dibawa. Watak-watak graduan seni persembahan dari universiti tempatan berdiskusi mengenai proposal pementasan berskala besar mereka dalam sebuah bilik studio menjadi ruang dramatik utama yang melatari pementasan dari awal hingga akhir. Dalam pementasan ini, terdapat adegan-adegan yang membawa para penonton ke ruang khayalan (imaginasi). Adegan-adegan tersebut meskipun tidak mengubah ruang realistik pementasan secara menyeluruh, tetapi memilih aspek-aspek lain yang boleh memberi panduan kepada penonton untuk merujuk kepada sesuatu ruang waktu dan tempat tertentu.

e ISSN 2735 - 1904

https://doi.org/10.22452/JOMAS.vol31no1.11 
Dalam satu adegan yang melibatkan teknik imbas kembali dalam Teater Juta-juta, watak Produser dan Pengarah melakonkan semula dua watak absurd dalam sebuah pementasan eksperimental yang pernah mereka pentaskan ketika zaman belajar di universiti di samping watak Sinografer yang bermonolog. Dalam tempoh kurang dari lima minit adegan itu berlangsung, ruang masa dan tempat telah bertukar dan membawa penonton berimaginasi ke dalam ruang pementasan eksperimental dengan gaya lakon serta perubahan cahaya yang drastik. Pertukaran ruang secara imaginatif dengan beberapa perubahan aspek teaterikal yang minima dilakukan secara konsisten dalam beberapa adegan lain seterusnya.

Bagi penulis-pengarah Aloy Paradoks dalam teater Merocok-rocok, ruang yang ditampilkan lebih bersifat absurd, tidak ada tanda-tanda atau setting khusus yang boleh memberi gambaran mengenai masa dan tempat drama itu berlaku. Ruang pentas yang dibiarkan kosong menjadi fleksibel kepada para pelakon beraksi dan membiarkan penonton secara bebas membayangkan tempat dan masa adegan-adegannya berlaku. Aloy Paradoks cuma membekalkan penonton dengan naratif, dialog-dialog puitis, perwatakan, gerak dan letak atur pelakon (blocking) yang setiap satunya berubah mengikut pecahan-pecahan adegan. Sebagai contoh, adegan soal siasat yang dilakukan oleh dua watak anggota polis berlaku ketika para pelakon dan korus yang lain berada dalam ruang lakon yang sama sambil duduk dalam bulatan. Tiga watak yang beraksi cuma dibezakan dengan kedudukan mereka yang berdiri dan cahaya lampu khusus disimbah ke atas mereka. Dalam keadaan ini, imaginasi penonton memainkan peranan untuk membawa ruang ini ke dalam sebuah bilik soal siasat bergantung seperti yang digambarkan dalam fikiran masing-masing. Teknik ruang imaginatif yang biasa dilihat dalam persembahan teater tradisional ini dieksperimenkan oleh Aloy Paradoks sebagai alternatif untuk menjelaskan ruang dramatiknya.

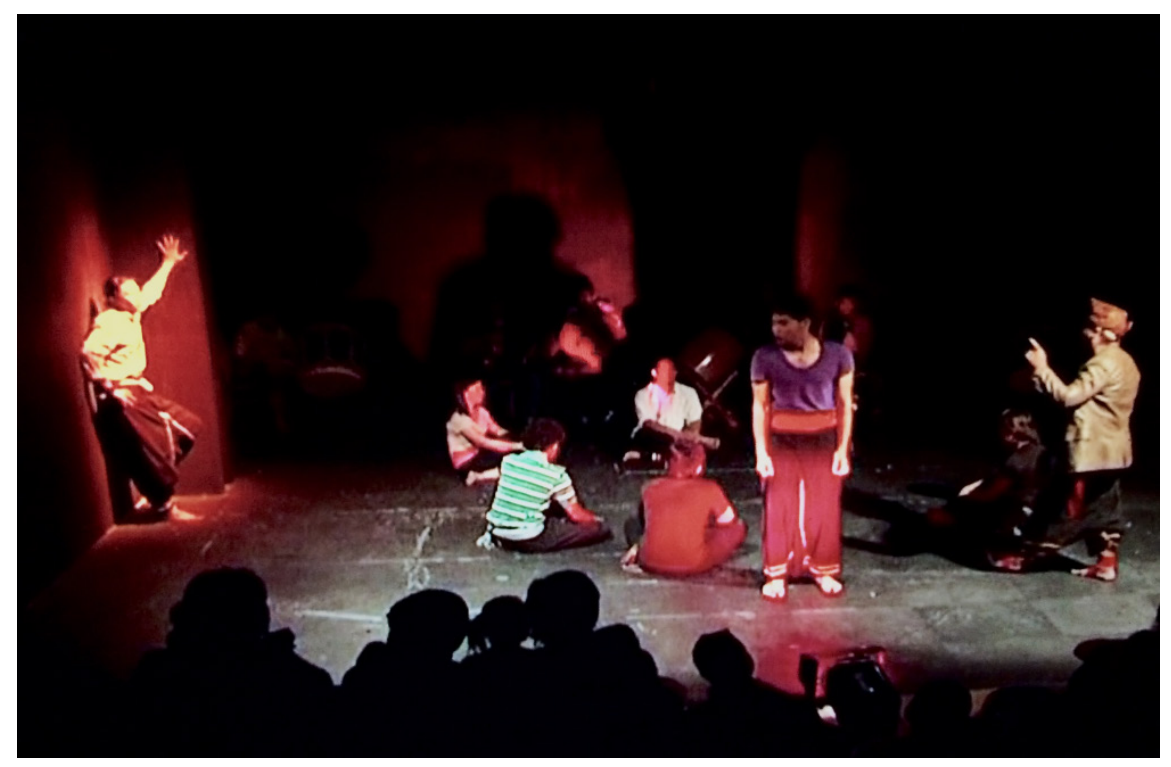

Gambar 1: Adegan soal siasat dijalankan di satu ruang yang sama dengan para pelakon dan korus yang tidak mengambil bahagian.

Teater Neo Romantik dilihat menggunakan pendekatan yang agak serupa dengan apa yang diterapkan dalam Merocok-rocok oleh Aloy Paradoks. Ruang imaginatif menjadi teras kepada konsep penjelasan latar waktu dan masa. Bezanya, dalam Neo Romantik, ruang masa dan tempat setiap adegan dijelaskan dengan aksi dua orang pelakon dengan bantuan satu props mudah alih berbentuk bangku dan tangga. Tanpa sebarang bantuan penataan set memberikan dorongan imaginasi visual yang lebih fleksibel 
kepada penonton. Latar masa kontemporari turut jelas boleh dikaitkan secara langsung melalui kostum, isu, dan gaya lakonan realistik pelakon. Ia dikuatkan lagi dengan satu bahagian khusus dalam pementasan, iaitu rancangan bual bicara diangkat sebagai babak. Bahagian ini berlangsung secara interaktif antara para pelakon dan penonton sekaligus menjadikan ia ciri-ciri yang mempunyai perkaitan zaman kontemporari. Dalam bahagian yang sama, para pelakon dan penonton berkongsi satu ruang secara bersama dan ia berlaku secara spontan.

Secara dasarnya, latar masa dan tempat yang digambarkan dalam kesemua teater yang dikaji adalah bertolak pada aspek imaginatif. Faktor ruang yang kecil di Stor Teater DBP itu sendiri menjadikan konsep yang popular bagi teater-teater pascamodenisme diketengahkan oleh penulis-pengarah. Ruang, masa dan tempat menjadi sesuatu yang lebih bersifat absurd, metafora dan khayalan seperti yang telah dibincangkan. Pada masa yang sama, khalayak penonton diberikan kebebasan dan turut sama berimaginasi sambil menonton untuk menggambarkan latar masa dan tempat mengikut apa yang mereka bayangkan. Selain itu, faktor kewangan turut memainkan peranan dalam menterjemahkan latar masa dan tempat dengan lebih realistik. Kebanyakan produksi teater alternatif ini tidak mempunyai modal yang besar.

\section{Kesimpulan}

Biarpun dalam kalangan penulis-pengarah teater alternatif Melayu di Stor Teater DBP yang dipilih berkongsi ruang yang sama, namun terdapat perbezaan jelas dari aspek proses penulisan karya masing-masing. Berdasarkan analisis yang dibuat terhadap sepuluh karya, pendekatan proses penulisan yang dipraktikkan boleh dibahagikan kepada dua, iaitu penulisan yang dihasilkan dari sumber idea naratif terlebih dahulu dan penulisan yang dihasilkan dari idea konsep pementasan. Penulis-pengarah yang lebih muda seperti Fasyali Fadzly dan Aloy Paradoks yang mempunyai latar pendidikan teater secara formal di universiti dalam bidang teater jelas mempraktikkan teori-teori pementasan ke dalam proses pengkaryaan mereka. Perkara ini tidak diletakkan prioriti bagi penulis-pengarah dari generasi yang seangkatan seperti Dinsman, A. Wahab Hamzah dan Nam Ron yang lebih cenderung menulis berdasarkan idea naratif terlebih dahulu biarpun mereka mempunyai pengalaman dan pengetahuan yang luas dalam seni pementasan teater. Ketigatiga penulis-pengarah ini juga turut dilihat mempunyai persamaan dalam memilih isu dan persoalan karya untuk diketengahkan dalam karya. Isu politik secara jelas dapat dilihat dalam karya-karya seperti Tamu dari Medan Perang, Menunggu Kata Dari Tuhan, Hering, Peristiwa di Malam Itu dan Matderihkolaperlih.

Unsur eksperimentasi dalam pengarahan turut menjadi salah satu faktor penting dalam mempengaruhi gaya pementasan teater alternatif. Hal ini bertolak pada penolakan terhadap permintaan ataupun keinginan khalayak penonton arus perdana. Dalam soal ini, ia bukan sahaja melibatkan pengisian mengenai aspek penulisan semata malah aspek teaterikal turut diutamakan dalam mengekspresi idea konsep teaterikal yang lebih segar dan baharu. Konsep eksperimentasi menjadi kelaziman bagi teater-teater alternatif seperti di Off-Broadway dan Off-Off Broadway dengan menghasilkan karya-karya eksperimental dengan menggabungkan pelbagai medium seni dalam pementasan seperti yang dilakukan oleh kumpulan Artists' Theater dan American Theater for Poets. Dalam kes teater alternatif Melayu di Stor Teater DBP, unsur-unsur eksperimentasi lebih menjadi pilihan terutamanya bagi penulis-pengarah muda seperti Fasyali Fadzly dan Aloy Paradoks. Kecenderungan mereka mempraktikkan penulisan berdasarkan konsep pementasan adalah bertolak dari pengaruh ilmu pengetahuan mereka mengenai teori-teori persembahan. Mereka telah didedahkan dengan proses pembelajaran di dalam studio ketika menuntut di universiti. Melalui sistem pembelajaran tersebut, teori-teori persembahan yang dipelajari selalunya dipraktikkan dalam setiap persembahan akhir mereka. Keadaan ini memberi ruang bagi mereka untuk mencuba setiap satu teori yang mereka pelajari dan fahami selain turut menggabungkannya menerusi proses kerja eksperimentasi dalam garapan karya.

Unsur-unsur hybrid dalam teaterikal jelas ditampilkan dalam pementasan teater Merocok-rocok dan

e ISSN 2735 - 1904

https://doi.org/10.22452/JOMAS.vol31no1.11 
Skala Kecil, Idea Besar: Kritikan Naratif

Terhadap Karya-Karya Teater Alternatif Di Stor Teater DBP

juga Teater Juta-juta, iaitu gabungan unsur baharu dan lama ditampilkan dengan lebih kontra diadun dalam satu pementasan. Aloy Paradoks memecahkan taboo dengan memasukkan unsur-unsur aksi sensual dengan sentuhan dan pelukan pasangan lelaki perempuan, kemudiannya diselangi dengan komposisi gerak tari randai turut dilihat satu pendekatan yang berani dan liberal. Unsur-unsur sebegini seakan memprovokasi tahap penerimaan khalayak teater alternatif dan membuka ruang pendebatan pasca pementasan. Pastinya jarang-jarang atau tidak berlaku dalam pementasan-pementasan arus perdana. Pada masa yang sama, ia turut menguatkan hujah untuk mengatakan bahawa penulis-pengarah muda lebih gemar untuk bereksperimentasi dengan pelbagai unsur teaterikal dalam karya mereka sehingga menjadikan karya-karya mereka memiliki gaya dan identiti yang tersendiri dan terpisah dari konvensional teater-teater arus perdana. Unsur eksperimentasi ini sekali gus memberikan cita rasa baharu dalam karya yang mampu menarik minat penonton muda.

Bagi penulis-pengarah yang mempunyai pengalaman yang lebih lama, aspek idea naratif menjadi faktor utama dalam mereka berkarya. Isu-isu dan persoalan-persoalan mengenai perkara yang berlaku di sekeliling mereka menjadi sumber utama kepada mereka untuk 'bercerita' kepada umum. Konsep ini juga seperti satu perkongsian pemikiran dan cara mereka berwacana dalam karya teater. Isu-isu keagamaan, politik, dan sosial menjadi pilihan untuk menyatakan pandangan mereka sendiri. Perbezaan karya-karya mereka berbanding penulis-pengarah yang lebih muda adalah dari segi pengisian teks. Persoalan-persoalan yang diangkat dalam karya-karya mereka adalah lebih berat dan sarat dengan dialog-dialog yang membawa maksud yang berlapis-lapis. Faktor ini turut menjadi satu kelebihan bagi karya-karya teater alternatif Melayu di Stor DBP, iaitu penonton tidak hanya disajikan pementasan teater yang bersifat teaterikal semata-mata malah turut diajak berdiskusi mengenai isu dan persoalan yang dilontarkan.

Penekanan terhadap aspek teks menjadikan teater alternatif Melayu mempunyai kekuatan tersendiri dengan kepelbagaian isu dan persoalan yang dilontarkan di dalamnya sekaligus menjadikan teks diisi dengan ideologi yang berbeza. Oleh itu, platform Stor Teater DBP turut menjadi tempat berdiskusi mengenai pelbagai topik berdasarkan terhadap isu yang diketengahkan oleh penulis-pengarah. Apa yang lebih menarik adalah karya yang dipentaskan itu tidak hanya bergantung kepada dialog-dialog dan naratif yang dipersembahkan untuk menggalas fungsinya sebagai sebuah pementasan yang berwacana. Ciri-ciri teaterikal yang digarap dalam kadar minima turut sama 'berdiskusi' mengenai rasa, emosi, dan fikiran penulis-pengarahnya yang lantas bepegang pada ideologi masing-masing.

Pementasan teater alternatif Melayu tidak bermodalkan aspek hiburan semata tetapi kepada idea keseluruhan pementasan, sama ada kualiti teks penulisannya mahupun aspek pementasannya. Tema-tema dan persoalan-persoalan yang diangkat dalam karya yang rata-ratanya mengutarakan isu-isu semasa yang serius dengan pelontaran persoalan-persoalan kritikal. Keadaan ini menyebabkan teater alternatif Melayu ini diberikan perhatian oleh nama-nama besar dalam dunia teater dan sastera termasuklah sasterawan negara seperti A Samad Said. Bahkan ada di kalangan nama besar seperti Faisal Tehrani, U Wei Saari, Sabri Yunus, Wan Hanafisu, Fauziah Nawi, S. M Zakir, dan Rahimidin turut menyumbang karya masing-masing di Stor Teater DBP sehingga menjadikan tempat ini berdiri dengan prestijnya yang tersendiri.

Ciri-ciri pementasan yang pelbagai dan tidak terikat dengan satu-satu gaya pementasan turut memperlihatkan kualiti yang tersendiri. Eksperimentasi bukan sesuatu yang menjadi elemen utama dalam kebanyakan pementasan teater alternatif Melayu. Pendekatan ini lebih kepada kecenderungan penulispengarah untuk menyesuaikan ciri-ciri ruang Stor Teater DBP yang terdapat halangan-halangan tertentu. Hasil dari penyesuaian tersebut, muncul idea-idea segar dari aspek teaterikal seperti yang diterapkan dalam penataan pencahayaan, set, dan busana. Tambahan pula dengan penampilan pelakon-pelakon terlatih dan berpengalaman menjadikan nilai tambah kepada kualiti pementasan itu. Lakonan dalam konteks teater dengan ruang intim ini menuntut ciri-ciri pelakon yang mempunyai kemahiran yang tinggi. Penelitian, ketenangan dan penumpuan yang tinggi diperlukan dalam membawakan setiap watak agar ia dapat menonjolkan kesan lakonan yang lebih meyakinkan. Apatah lagi dalam kebanyakan teater yang dipentaskan

e ISSN 2735 - 1904

https://doi.org/10.22452/JOMAS.vol31no1.11 
melibatkan penampilan pelakon yang minimum termasuk sebilangan besar yang menampilkan pelakon secara solo atau berkonsepkan monodrama seperti teater Laut Lebih Indah dari Bulan, Matderihkolaperlih, Kotak Hitam, dan Menunggu Kata dari Tuhan.

Walau bagaimanapun, jika dilihat berdasarkan sepuluh pementasan teater alternatif Melayu yang dikaji, penulis-pengarah juga turut mengoptimumkan idea pementasan dengan tidak terlalu terbatas dengan limitasi ruang dan konsep-konsep persembahan teater lain yang pernah sebelumnya dipentaskan di Stor Teater. Setiap penulis-pengarah mempunyai pendekatan dan citarasa yang berbeza mengikut gaya mereka tersendiri. Namun, tidak dinafikan terdapat beberapa persamaan dalam beberapa aspek pementasan mereka rentetan dari faktor ruang yang ketara. Aspek ruang berskala kecil yang menuntut penulis-pengarah membataskan bilangan pelakon dan meminimumkan penggunaan set dan props adalah salah satu unsur yang menjadi identiti kepada teater alternatif Melayu di Stor Teater DBP. Selain itu, terdapat elemenelemen segar dan kontemporari seperti unsur parodi, muzikal, hybrid, dan interaktif bersesuaian dengan selera penonton masa kini. Kepelbagaian konsep dan gaya persembahan teater alternatif Melayu ini boleh dikatakan sesuatu yang unik, fleksibel dan tersendiri kesan dari faktor ruang dan masa yang telah dibincangkan. Proses pengkaryaan teater oleh penulis-pengarah teater alternatif Melayu boleh dikatakan mempunyai fleksibiliti dari aspek naratif dan pementasan. Kecenderungan menggarap idea awal penulispengarah dalam menghasilkan karya mereka dilihat tidak lebih hanya sebagai satu pendekatan mengikut keserasian masing-masing. Kesemua yang dijadikan informan mengawal secara langsung kedua-dua hal penulisan dan pengarahan dalam masa yang sama. Situasi ini memudahkan lagi proses kreativiti berlaku kerana mereka sendiri mempunyai kebebasan dalam mengolah naratif, malah pada masa yang sama menentukan aspek teaterikal yang bersesuaian.

\section{Rujukan}

A. Wahab Hamzah. (2005). Hering. Kuala Lumpur: Penulis.

. (2008). Peristiwa Malam Itu. Kuala Lumpur: Penulis.

(2009). Stor Teater DBP Pemangkin Dramatis Muda. Retrieved from Utusan online:

www.utusan.com.my/hiburan/stor-teater-dbp-pemangkin-dramatis-muda-1.230752.

. (07.04.2016). Penulis-pengarah teater Hering dan Peristiwa di Malam Itu. Temubual Peribadi. Selangor.

Aloy Paradoks. (2008). Neo-Romantik. Kuala Lumpur: Penulis.

. (2011). Merocok-rocok. Kuala Lumpur: Penulis.

. (23.5.2016). Penulis-pengarah teater Merocok-rocok dan Neo-Romantik. Temubual Peribadi. Kuala Lumpur.

Culler, J. (1994). Structuralist poetics: Structuralism, linguastics and the study of literature. London: Routledge.

Dinsman. (1979). Bukan Bunuh Diri. Kuala Lumpur: Dewan Bahasa dan Pustaka. . (2006). Tamu Dari Medan Perang. Shah Alam, Selangor: Teater Elit. . (2009). Menunggu kata dari Tuhan. Shah Alam, Selangor: Teater Elit.

(25.05.2016). Penulis-pengarah teater Menunggu kata dari Tuhan dan Tamu di Medan Perang.

Temubual Peribadi. Shah Alam.

Fasyali Fadzly. (2011). Kotak Hitam. Kuala Lumpur: Penulis.

. (2013). Teater Juta-juta. Kuala Lumpur: Penulis.

e ISSN 2735 - 1904

https://doi.org/10.22452/JOMAS.vol31no1.11 
Skala Kecil, Idea Besar: Kritikan Naratif Terhadap Karya-Karya Teater Alternatif Di Stor Teater DBP . (14.04.2016). Penulis-pengarah teater Kotak Hitam dan Teater Juta-juta. Temubual Peribadi. Shah Alam.

Fauzi Hassan., Tengku Intan Marlina, T. M. A., \& Madiawati, M@M. (2019). Subjektiviti dalam novel-novel terpilih Faisal Tehrani. Jurnal Pengajian Melayu/Journal of Malay Studies (JOMAS),30(1),28-52. Retrieved from https://ejournal.um.edu.my/index.php/JPM/article /view/21222

Grams, T. (2017). Classical Masculinity in Shakespeare's Antony and Cleopatra. Marquette Michigan: LAP Lambert Academic Publishing.

Hill, A. (2005). Reality TV: Audiences and Popular Factual Television. New York: Routledge.

Jones, L.L. (2002). Essays on Documenting and Researching Modern Productions of Greek Drama: The Sources. Retrieved from www2.open.ac.uk/ClassicalStudies/GreekPlays.

Knight, K. (2014). Real places and impossible spaces: Foucault's Heterotopia in the fiction of James Joyce, Vladimir Nabokov, and W.G. Sebald (Unpublished Doctoral thesis). University of East Anglia. Norwich.

Lethbridge, S. \& Mildorf, J. (2008). Basics of English studies. Freiburg: English Department, Freiburg University Germany.

Liina, U. (2002). Creating the Place. Place and Location II. Proceedings of the Estonian Academy of Arts 10, eds. V. Sarapik, K. Tüür, M. Laanemets. Tallinn: Eesti Kunstiakadeemia 2002, pp. 361-369.

Mohd Effindi Samsuddin. (2007). Perubahan corak kerja kreatif bangsawan: Satu kesinambungan identiti. Jurnal Pengajian Melayu/Journal of Malay Studies (JOMAS), 18(1), 57-85. Retrieved from https://ejournal.um.edu.my/index.php/JPM/article/view/9730.

Nam Ron. (2012). Laut lebih indah dari bulan: Antologi Skrip Teater Nam Ron. Petaling Jaya: Merpati Jingga. . (2006). Laut lebih indah dari bulan. Kuala Lumpur: Penulis. . (2012). Matderihkolahperlih. Kuala Lumpur: Penulis.

. (2016). Penulis-pengarah teater Laut Lebih Indah dari Bulan dan Matderihkolaperlih. Temubual Peribadi pada 14 April 2016, Kuala Lumpur.

Natalie, A. (2009)_How black box theatre came of age. Retrieved from https://www.theguardian.com/stage/ theatreblog/2009/jun/23/black-box-theatre.

Rahmah Bujang. (2007). Fungsi komunikasi dan estetika dalam persembahan teater tradisional wayang kulit. Jurnal Pengajian Melayu/Journal of Malay Studies (JOMAS), 18(1), 135-156. Retrieved from https://ejournal.um.edu.my/index.php/JPM/article/view/9740.

e ISSN 2735 - 1904

https://doi.org/10.22452/JOMAS.vol31no1.11 